\title{
EKSPLORASI DAMPAK NEGATIF DAN POSITIF PENGALAMAN BODY SHAMING MELALUI PENDEKATAN AUTOETNOGRAFI
}

\author{
Annisa Dwi Astuti \& Winarini Wilman D. Mansoer \\ Fakultas Psikologi Universitas Indonesia, Jl. Margonda Raya, Pondok Cina, Kecamatan Beji, Depok, Jawa Barat 16424, Indonesia
}

Korespondensi: annisa.dwi93@ui.ac.id

\section{EXPLORATION OF THE NEGATIVE AND POSITIVE IMPACT OF BODY SHAMING EXPERIENCE THROUGH AUTOETHNOGRAPHY APPROACH}

\begin{abstract}
Body shaming, or humiliating someone because of her or his body, regardless performed by oneself or by others, can elicit negative response to the victim. This autoethnography study aims to find out how individuals interpret their body shaming experiences. Participants were the first author and two young adult women who had similar body shaming experiences. The results showed that body shaming experiences raised negative emotions in all participants. However, the impact varies for each participant. The results of the study are summarized in seven significant themes: the emergence of body shaming, reasons for diet, the negative impacts, coping strategies, body shaming during and after diet, the positive impact, and support for dealing with body shaming. This study is expected to increase public understanding of the body shaming phenomenon, the impacts, and the various strategies to overcome the experiences of body shaming.
\end{abstract}

Manuscript type: Original Research

\section{Article history:}

Received 21 September 2020

Received in revised form 4 October 2020

Accepted 18 November 2020

Available online 24 March 2021

\section{Keywords:}

autoethnography

body shaming

negative impact

positive impact

\begin{abstract}
Abstrak
Body shaming, atau mempermalukan seseorang karena bentuk tubuhnya, baik yang dilakukan oleh diri sendirì maupun orang lain, dapat memicu respons negatif terhadap korban. Studi autoetnografi ini bertujuan untuk menggali bagaimana individu memaknai pengalaman malu terkait tubuh. Partisipan adalah peneliti sendiri dan dua orang wanita dewasa muda yang memiliki pengalaman malu terkait tubuh. Hasil studi ini menunjukkan bahwa pengalaman malu terkait tubuh memunculkan emosi negatif pada semua partisipan. Akan tetapi, terdapat dampak yang berbeda di setiap partisipan. Hasil studi dirangkum dalam tujuh tema besar, yaitu kemunculan malu terkait tubuh, alasan melakukan diet, dampak negatif, strategi koping, malu terkait tubuh saat dan setelah diet, dampak positif, dan dukungan menghadapi malu terkait tubuh. Penelitian ini diharapkan dapat meningkatkan pemahaman masyarakat tentang fenomena malu terkait tubuh, dampaknya, dan berbagai strategi untuk mengatasi pengalaman tersebut.
\end{abstract}

Kata Kunci: autoetnografi, dampak negatif, dampak positif, malu terkait tubuh

\section{Dampak dan Implikasi dalam Konteks Ulayat}

Di Indonesia, mengomentari atau mengkritik bentuk tubuh sebagai topik untuk membuka percakapan adalah hal yang biasa dilakukan. Penelitian ini menunjukkan bahwa mengomentari bentuk tubuh dapat memunculkan emosi negatif bagi yang mengalaminya, namun juga berdampak positif dalam beberapa hal. Dampak negatif maupun positif yang dialami berbeda setiap orang. Hasil menunjukkan bahwa dampak positif seperti perubahan gaya hidup, adanya dukungan sosial, dan strategi koping yang adaptif dapat meminimalkan dampak negatif. Kekhasan Indonesia terlihat dari diperlukannya dukungan sosial dari orang terdekat hingga figur idola yang menginspirasi. Secara khusus, hasil ini dapat digunakan oleh praktisi klinis dalam menyusun metode dan rancangan intervensi yang tepat bagi individu dengan cara membantu individu mengidentifikasi sumber dukungan, baik yang berupa orang terdekat maupun karya yang menginspirasi. Dengan cara ini diharapkan individu mampu mengembangkan koping efektif. 


\section{PENDAHULUAN}

Pada masyarakat di kota-kota besar saat ini, kesadaran akan pentingnya memiliki berat badan dan bentuk tubuh ideal sangat tinggi, baik untuk alasan kesehatan maupun untuk keindahan, terutama pada perempuan. Penelitian menunjukkan bahwa secara signifikan perempuan lebih mementingkan penampilan tubuhnya dan cenderung tidak puas terhadap tubuhnya dibandingkan laki-laki (Quittkat dkk., 2019). Kondisi ini tidak terlepas dari pengaruh gambaran tubuh ideal yang sangat gencar ditampilkan oleh media. Orang-orang dengan berat badan yang berlebih seakan-akan mendapat stigma tidak sehat, tidak menarik, bahkan mengerikan (Webb dkk., 2016). Berbagai metode diet untuk menurunkan berat badan pun diajukan oleh para ahli gizi, seperti diet keto, diet mediterranean, diet vegan, diet kalori rendah, dan lain-lain (Newman, 2017). Ketika individu menganggap tidak mampu memenuhi standar tubuh ideal, ia rentan untuk mendapat perlakuan dipermalukan terkait bentuk tubuhnya dari lingkungannya. Kritik terhadap tubuh tidak hanya terbatas pada berat badan berlebih, tetapi juga pada tubuh yang terlalu kurus. Kedua tipe tersebut terjadi pada masyarakat patriarki, di mana penilaian tubuh wanita dilakukan melalui evaluasi dan komentar orang lain (Bordo, 1993). Fenomena ini juga menjelaskan adanya weight bias, yaitu bentuk tubuh dipandang sebagai sifat utama yang membawa informasi tentang karakteristik lain yang dianggap dimiliki oleh seorang wanita (Yoder, 2013). Bentuk-bentuk kritik ini juga dapat dilakukan terkait ukuran tubuh, ketidaksempurnaan tubuh, maupun penampilan fisik lainnya (Soleman \& Elindawati, 2019). Pada konteks penelitian ini, pembahasan hanya akan difokuskan pada komentar atau kritik yang diberikan akibat kelebihan berat badan.

Body shame (malu terkait tubuh) adalah konsep yang menunjukkan adanya kesadaran diri dan respon negatif terhadap diri sendiri. Malu terkait tubuh dapat dilakukan oleh diri sendiri maupun orang lain. Hal ini dilakukan untuk memenuhi standar tubuh ideal dan pengakuan atas kegagalan memenuhi standar budaya (Fredrickson \& Roberts, 1997). Banyaknya fenomena malu terkait tubuh dan faktor-faktor yang menyebabkannya membuat istilah ini mengalami perkembangan. Malu terkait tubuh menjadi tren dengan istilah body shaming (Chairani, 2018). Menurut Vargas (n.d.) terdapat beberapa ciri-ciri perilaku malu terkait tubuh, yaitu: 1). mengkritik penampilan sendiri melalui penilaian atau perbandingan dengan orang lain; 2). mengkritik penampilan orang lain di depan orang itu; dan 3). mengkritik penampilan orang lain tanpa sepengetahuan orang tersebut.

Malu terkait tubuh dapat memberikan dampak bagi kesehatan fisik maupun kesehatan mental. Penelitian menunjukkan bahwa malu terkait tubuh menghasilkan stigma negatif yang memberikan 
pengaruh buruk bagi kesehatan dan kesejahteraan fisik maupun psikologis (Tylka dkk., 2014). Malu terkait tubuh memiliki hubungan dengan citra tubuh (body image) dan ketidakpuasan tubuh (body dissatisfaction). Citra tubuh adalah bagaimana seseorang secara internal menilai tubuhnya sendiri, baik dalam wujud berat, bentuk, ukuran, dan kapabilitas tubuh (Veerman, 2013). Ketidakpuasan tubuh adalah ketidakpuasan individu terhadap tubuhnya. Malu terkait tubuh yang dilakukan oleh teman sebaya dapat memengaruhi citra tubuh dan ketidakpuasan terhadap tubuh. Tekanan dari teman sebaya untuk menjadi kurus menjadi faktor risiko seorang individu mengalami ketidakpuasan terhadap tubuh. Perbandingan dengan teman sebaya juga dapat menghasilkan citra tubuh yang negatif. Citra tubuh negatif juga diakui sebagai hal yang berkontribusi dalam berkembangnya gangguan makan yang apabila tidak ditangani dapat mengancam hidup (Veerman, 2013). Persepsi yang salah terhadap citra tubuh dan ketidakpuasan terhadap tubuh akibat malu terkait tubuh dapat menjadi sumber stres dan mengarah kepada gangguan makan.

Penelitian menunjukkan terdapat hubungan antara strategi pengelolaan stres dalam menghadapi malu terkait tubuh dengan gangguan makan. Malu terkait tubuh secara signifikan berhubungan positif dengan strategi menghindar dan memodifikasi penampilan (Bailey dkk., 2016). Strategi yang tidak tepat seperti menghindar, rasionalisasi, dan memodifikasi penampilan atau bentuk tubuh berhubungan dengan hasil negatif, seperti gangguan makan dan depresi (Farid \& Kamrani, 2016). Strategi tersebut berfokus pada emosi. Sementara itu, ada strategi yang berfokus untuk yang menyelesaikan masalah secara rasional dan realistis (Lazarus \& Folkman, 1984). Secara spesifik, strategi yang efektif untuk menghadapi malu terkait tubuh adalah menyayangi diri sendiri (selfcompassion) yang secara signifikan mengurangi ketidakpuasan terhadap tubuh, malu terkait tubuh, dan keberhargaan diri yang rendah terkait penampilan (Albertson dkk., 2015).

Hubungan yang kuat antara malu terkait tubuh dan gangguan makan memberi gambaran bahwa malu terkait tubuh dapat menjadi prediktor yang sangat kuat terhadap gangguan makan (Chairani, 2018). Menurut American Psychiatric Association (2013), gangguan makan ditandai oleh gangguan patologis, sikap, dan perilaku yang berhubungan dengan makanan. Gangguan makan tersebut terdiri dari: anoreksia nervosa, bulimia nervosa, dan binge-eating. Selain gangguan yang bersifat klinis, gangguan makan juga dapat bersifat non-klinis, seperti metode pengaturan berat badan yang tidak sehat, makan berlebihan, kegemaran makan yang menyimpang, sikap dan perilaku yang terkait dengan bentuk badan, berat badan, citra tubuh, serta makanan (Katz, 2014). Apabila gangguan makan sudah berada di tahap klinis, akan sulit bagi individu yang mengalaminya untuk dipulihkan 
dan dapat menyebabkan efek yang serius terhadap fisik, psikologis, rentan terhadap penyakit, dan kematian (Veerman, 2013).

Di Indonesia, fenomena malu terkait tubuh ini dianggap sebagai hal yang serius. Hal ini ditunjukkan melalui Pasal 27 Ayat (3) Undang Undang Infomasi dan Transaksi Elektronik mengenai penghinaan citra tubuh melalui media sosial (Undang-Undang Republik Indonesia Nomor 11, 2008). Di sisi lain, fenomena malu terkait tubuh masih banyak terjadi. Penelitian sebelumnya menunjukkan bahwa malu terkait tubuh banyak terjadi pada remaja di Indonesia karena berkaitan dengan perubahan bentuk tubuh saat masa pubertas dan pembentukan identitas diri (Fauzia \& Rahmiaji, 2019; Pricilia dkk., 2019; Rosita dkk., 2019). Penelitian yang dilakukan pada perempuan dewasa awal di Indonesia juga menunjukkan bahwa malu terkait tubuh berasal dari penilaian dimana tubuh dipandang sebagai objek (self-objectification) (Damanik, 2018). Memandang tubuh sebagai objek, tidak hanya dipengaruhi penilaian diri sendiri, tetapi juga faktor eksternal berupa penilaian atau komentar orang lain. Hal ini sejalan dengan penelitian bahwa malu terkait tubuh di Indonesia disebabkan karena tatanan sosial yang membentuk kebiasaan sehari-hari masyarakat (Soleman \& Elindawati, 2019). Kritik terkait tubuh biasa dilakukan untuk mengungkapkan ketidaksetujuan dan ketidaknyamanan terkait bagian tubuh orang lain karena tidak sesuai dengan konstruk tubuh ideal yang ada di pikiran seseorang. Kebiasaan ini membentuk kerangka berpikir bahwa memberikan kritik terkait tubuh adalah sesuatu yang normal untuk dilakukan. Hal ini menyebabkan fenomena malu terkait tubuh masih banyak terjadi di Indonesia, walaupun memiliki berbagai dampak negatif (Soleman \& Elindawati, 2019).

Meski fenomena malu terkait tubuh di Indonesia sudah mulai banyak diteliti, penelitian terkait fenomena malu terkait tubuh pada usia dewasa muda masih terbatas. Lebih lanjut, penelitianpenelitian sebelumnya menekankan pada banyak dampak negatif dari malu terkait tubuh (Chairani, 2018), tetapi masih sedikit yang menjelaskan bagaimana dinamika individu saat mengalaminya (Damanik, 2018). Penelitian ini dibutuhkan untuk memberikan gambaran strategi pengelolaan yang dapat dilakukan untuk meminimalisasi dampak malu terkait tubuh.

Sebagai mahasiswa Program Studi Magister Psikologi Profesi Klinis Dewasa dan pernah memiliki pengalaman malu terkait tubuh, saya dalam kapasitas sebagai penulis pertama tertarik untuk memahami malu terkait tubuh dan dampaknya dari pengalaman saya sendiri dan pengalaman orang lain melalui pendekatan autoetnografi. Pendekatan ini diharapkan dapat menggugah individu bahwa malu terkait tubuh dapat dialami siapa saja, memberikan dukungan kepada individu yang memiliki pengalaman yang sama, dan meningkatkan empati kepada individu lainnya terkait fenomena ini. 
Pendekatan autoetnografi ini dapat memberi perspektif yang memperkaya perkembangan ilmu psikologi, khususnya fenomena malu terkait tubuh di Indonesia. Selain itu, diharapkan dari pemahaman ini, praktisi psikologi klinis dewasa lainnya mendapat informasi yang bermanfaat dalam menangani individu yang mengalami malu terkait tubuh beserta segala dampak negatif yang menyertainya.

\section{METODE}

\section{Partisipan}

Partisipan dalam studi ini adalah peneliti utama (penulis pertama yang selanjutnya hanya disebut peneliti) dan dua individu lain yang sama-sama mengalami malu terkait tubuh karena memiliki berat badan yang dianggap berlebihan atau tubuh yang dianggap gemuk. Indeks masa tubuh (BMI) partisipan dihitung berdasarkan berat badan (dalam $\mathrm{kg}$ )/tinggi badan (dalam $\mathrm{m}^{2}$ ) untuk mengetahui tiap partisipan masuk ke dalam kategori BMI yang mana saat mengalami pengalaman malu terkait tubuh. Kriteria BMI ditentukan berdasarkan kriteria World Health Organization (WHO) yaitu underweight $\left(<18.5 \mathrm{~kg} / \mathrm{m}^{2}\right)$, berat badan normal $\left(18.5-<23 \mathrm{~kg} / \mathrm{m}^{2}\right)$, overweight $(23-<27.5$ $\left.\mathrm{kg} / \mathrm{m}^{2}\right)$, dan obese $\left(\geq 27.5 \mathrm{~kg} / \mathrm{m}^{2}\right.$ ) (Nishida dkk., 2004).

Partisipan pertama adalah peneliti. Peneliti berusia 28 tahun, anak kedua dari dua bersaudara, mahasiswa S2 Magister Psikologi Profesi Klinis Dewasa, dan belum menikah. Ketika pengalaman malu terkait tubuh terjadi, peneliti memiliki berat badan yang dapat dikategorikan obese (berat badan $=83 \mathrm{~kg}$, tinggi badan $=156 \mathrm{~cm}, \mathrm{BMI}=34.1)$. Anggota keluarga peneliti memiliki bentuk tubuh yang normal tanpa memiliki pengalaman malu terkait tubuh.

Partisipan A adalah seorang perempuan berusia 29 tahun, anak ketiga dari tiga bersaudara, berlatar belakang pendidikan S3, dan belum menikah. Ketika pengalaman malu terkait tubuh terjadi, partisipan A pernah memiliki berat badan yang dapat dikategorikan normal (berat badan $=55 \mathrm{~kg}$, tinggi badan $=160 \mathrm{~cm}, \mathrm{BMI}=21.5$ ). Selain A, kedua kakak A memiliki bagian tubuh tertentu yang rentan mengalami pengalaman malu terkait tubuh. Partisipan A menyampaikan bahwa dirinya dan dua orang kakaknya memiliki ukuran betis yang besar yang diturunkan dari ibunya. Ibu dari A sering menyampaikan bahwa kakak pertama A mendapatkan bentuk badan yang tidak indah yang diturunkan dari neneknya.

Partisipan B adalah seorang perempuan berusia 27 tahun, anak ketiga dari tiga bersaudara, berlatar belakang pendidikan S2, dan sudah menikah. Ketika pengalaman malu terkait tubuh terjadi, 
partisipan B memiliki berat badan yang dapat dikategorikan obese (berat badan $=99 \mathrm{~kg}$, tinggi badan $=165 \mathrm{~cm}, \mathrm{BMI}=36.4$ ). Kakak pertama B juga memiliki kerentanan mengalami pengalaman malu terkait tubuh karena memiliki berat badan yang dapat dikategorikan obese (berat badan $=110 \mathrm{~kg}$, tinggi badan $=170 \mathrm{~cm}, \mathrm{BMI}=38.1$ ). Baik partisipan A dan B bersedia terlibat dalam penelitian ini setelah membaca tulisan-tulisan peneliti di media sosial (akun Instagram) tentang pengalaman malu terkait tubuh yang peneliti alami.

\section{Desain}

Penelitian ini adalah penelitian kualitatif dengan pendekatan autoetnografi. Pendekatan autoetnografi merupakan pendekatan dengan pengetahuan yang kompleks dan spesifik mengenai kekhasan dan keistimewaan sebuah pengalaman, kehidupan, dan hubungan tertentu (Adams dkk., 2015). Pendekatan autoetnografi menggunakan pengalaman pribadi peneliti dalam menilai dan/atau memberi kritik pengalaman budaya secara umum (Jones dkk., 2016). Salah satu jenis autoetnografi adalah collaborative autoethnography, yaitu metode autoetnografi yang melibatkan orang lain sebagai partisipan (Jones dkk., 2016). Metode ini adalah metode baru yang memungkinkan peneliti untuk meneliti diri sendiri dan orang lain yang memiliki pengalaman yang mirip. Metode ini memungkinkan peneliti untuk memiliki kerentanan terhadap orang lain, seperti orang lain memiliki kerentanan yang sama terhadap peneliti.

\section{Pengumpulan Data}

Data penelitian ini dibagi menjadi dua, yaitu data yang diperoleh dari peneliti dan data yang diperoleh dari dua partisipan lainnya. Data yang diperoleh dari peneliti berasal dari catatan jurnal, catatan di media sosial, dan dokumentasi pribadi milik peneliti. Adapun data yang diperoleh dari dua partisipan lainnya berasal dari hasil refleksi mandiri dan wawancara. Peneliti memberikan pertanyaan kepada partisipan, yaitu "Bagaimana pengalaman malu terkait tubuh yang Anda rasakan?” yang kemudian direfleksikan secara mandiri oleh partisipan. Selanjutnya peneliti melakukan wawancara sebagai tindak lanjut hasil refleksi mandiri tersebut. Peneliti mengajukan kembali pertanyaan utama dan menambahkan pertanyaan-pertanyaan lanjutan (probing) yang relevan. Pelaksanaan wawancara disesuaikan dengan ketersediaan waktu partisipan. Pada penelitian ini, partisipan mendapatkan lembar penjelasan yang berisi tujuan penelitian dan permohonan izin untuk merekam dan mendokumentasikan proses wawancara, kemudian mengisi lembar persetujuan partisipasi dalam penelitian. 


\section{Prosedur}

Penelitian ini telah dinyatakan memenuhi persyaratan oleh Komite Etik Penelitian Fakultas Psikologi Universitas Indonesia dengan Nomor 758/FPsi. Komite Etik/PDP.04.00/2020. Pengumpulan data dilakukan dalam dua tahap, yaitu pengumpulan data terkait peneliti dan pengumpulan data terkait partisipan. Pengumpulan data terkait peneliti dimulai dengan melakukan refleksi mandiri dengan bantuan catatan jurnal peneliti, tulisan yang pernah peneliti unggah di akun Instagram, dan dokumentasi pribadi yang peneliti miliki. Tahapan ini membutuhkan waktu 3 hari. Tulisan-tulisan yang pernah peneliti unggah di akun Instagram mendapat tanggapan yang positif dari orang-orang yang membacanya, termasuk dari individu yang juga mengalami pengalaman malu terkait tubuh yang serupa. Tanggapan-tanggapan tersebut kemudian dilanjutkan menjadi diskusi personal dan beberapa orang mau membuka dirinya lebih jauh.

Peneliti kemudian meminta dua dari orang-orang yang bersedia menceritakan pengalaman malu terkait tubuhnya, khususnya pengalaman malu terkait tubuh karena dianggap memiliki tubuh yang gemuk atau berat badan yang berlebihan, untuk terlibat menjadi partisipan penelitian ini. Setelah bersedia, tahapan pengumpulan data partisipan dimulai. Peneliti kemudian meminta partisipan untuk melakukan refleksi secara mandiri kemudian diwawancarai sebagai partisipan. Durasi pengambilan data ini dilakukan selama 2 hari, yaitu hari pertama untuk refleksi secara mandiri dan hari kedua untuk wawancara melalui video call. Adapun durasi wawancara dilakukan selama 2 jam.

\section{Teknik Analisis}

Peneliti melakukan evaluasi pengalaman malu terkait tubuh yang dialami diri sendiri kemudian menuliskannya dalam bentuk narasi. Adapun refleksi mandiri kedua partisipan dan rekaman wawancara partisipan dibuat dalam bentuk verbatim oleh peneliti. Peneliti kemudian melakukan analisis dari kedua data tersebut dengan menggunakan teknik analisis phenomenological reduction, imaginative variation, dan synthesis (Moustakas, 1994). Pada tahap phenomenological reduction, peneliti bekerja sama untuk memilih fokus penelitian dan memilah data sehingga memunculkan tema-tema pada penelitian. Pada tahap ini ditemukan persamaan dan perbedaan pengalaman malu terkait tubuh pada seluruh partisipan. Pada tahap imaginative variation, peneliti berusaha memahami hal-hal yang menyebabkan pengalaman tersebut terjadi berdasarkan data yang diperoleh. Pada tahap synthesis, peneliti melakukan proses integrasi data menjadi satu kesatuan utuh yang dapat menggambarkan dan mewakili fenomena secara keseluruhan. Pada proses refleksi pengalaman peneliti, terdapat tingkat subjektivitas yang tinggi sehingga berpotensi untuk 
memengaruhi pengalaman partisipan. Kondisi ini diantisipasi dengan cara analisis dan intepretasi tidak hanya dilakukan oleh peneliti sebagai penulis pertama, tetapi juga didiskusikan bersama dengan penulis kedua dalam kapasitas sebagai pembimbing peneliti.

\section{ANALISIS DAN HASIL}

Berdasarkan hasil refleksi pengalaman peneliti, refleksi mandiri partisipan lain, dan wawancara yang dilakukan kepada partisipan, terdapat tujuh tema yang dimaknai berbeda antar partisipan, yaitu: kemunculan malu terkait tubuh, alasan melakukan diet, dampak negatif, strategi koping, malu terkait tubuh saat dan setelah diet, dampak positif, dan dukungan menghadapi malu terkait tubuh. Sebelum membahas tema-tema tersebut, akan dijabarkan terlebih dahulu latar belakang yang dimiliki partisipan.

\section{Latar Belakang}

Peneliti, A, dan B, memiliki latar belakang yang berbeda, khususnya terkait hal-hal yang dianggap penting yang ditanamkan sejak kecil. Dalam kasus peneliti, sejak kecil orang tua peneliti lebih sering mengapresiasi karya, prestasi, dan kontribusi peneliti untuk orang lain dibandingkan penampilan fisik. Peneliti lebih sering mendengar orang tua membanggakan peneliti kepada tetangga terkait aktivitas dan prestasi yang diperoleh, seperti saat juara lomba mengarang di sekolah, ketika menjadi ketua kelas di sekolah, dan ketika menjadi pengurus OSIS. Apresiasi ini membentuk konsep diri peneliti, yaitu bahwa yang penting adalah karya, prestasi, dan melakukan kegiatan yang bermanfaat untuk orang lain, bukan penampilan fisik. Selain itu, salah satu kalimat orang tua peneliti yang sering diulang-ulang, "Kita harus hidup prihatin. Kalau susah, jangan nyerah." Kalimat ini terinternalisasi dalam diri dan membuat peneliti berusaha untuk menghadapi berbagai tantangan. Peneliti relatif sehat dan tidak memiliki keluhan terkait bentuk tubuh maupun berat badan tanpa memiliki kebiasaan olah raga rutin maupun mengatur pola makan. Peneliti menjalani tahapan perkembangan kehidupan dengan lancar.

Hal ini berbeda dengan pengalaman partisipan A dan B, di mana penampilan fisik merupakan hal yang penting di keluarga. A (29 tahun) sejak kecil sering dikomentari terkait penampilan fisik oleh keluarganya. 
Kalau orang-orang di rumah aku, kayak mamaku suka komen. Kalau aku pake tshirt gitu yang lengannya pendek, itu mamaku suka komen: "Ih jangan pake baju kayak gitu. Kalau kamu pake baju kayak gitu pake cardigan lagi, soalnya lengan kamu gede banget”.

Adapun B (27 tahun) sejak kecil diajarkan bahwa bentuk tubuh yang besar dapat disiasati dengan pakaian:

Waktu kecil keluarga gue sering banget bilang: "Kamu tuh cantik, gak papa badannya gemuk, tinggal pake baju hitam, nanti kita modifikasi biar keliatan kurus. Pokoknya yang penting gimana cara menyiasatinya, biar tetep cantik diliatnya." Itu sering banget disampein keluarga gue.

Berdasarkan hal tersebut, terlihat bahwa terdapat perbedaan latar belakang keluarga yang mempengaruhi peneliti, A, dan B, di mana penampilan fisik tidak menjadi hal yang utama yang ditanamkan pada keluarga peneliti sedangkan pada keluarga A dan B penampilan fisik merupakan hal yang penting dan menjadi sorotan utama.

\section{Kemunculan Malu terkait Tubuh}

Waktu kemuculan malu terkait tubuh juga berbeda antara peneliti dengan A dan B. Peneliti mengalami malu terkait tubuh ketika usia dewasa. Saat berusia 26 tahun, peneliti bekerja di sebuah institusi pemerintahan. Tuntutan pekerjaan yang cukup tinggi membuat peneliti mengalami stres kerja. Demi bisa berfungsi dan bekerja dengan baik di tengah stres dan tekanan tersebut, makan berlebihan menjadi pilihan pelampiasan yang peneliti ambil. Porsi makan peneliti jauh lebih banyak dengan tujuan untuk mengurangi kecemasan dan ketegangan yang peneliti alami. Sebelumnya berat badan peneliti cenderung overweight (berat badan $=65 \mathrm{~kg}$, tinggi badan $=156 \mathrm{~cm}, \mathrm{BMI}=26.7$ ). Hal ini diperburuk dengan kurangnya aktivitas fisik karena pekerjaan peneliti lebih banyak bersifat administratif. Pelarian kepada makanan akibat stres kerja menyebabkan peneliti mengalami obesitas dengan berat badan peneliti mencapai $83 \mathrm{~kg}$ (tinggi badan $=156 \mathrm{~cm}, \mathrm{BMI}=34.1)$. Berat badan ini menjadi berat badan yang paling berat yang pernah peneliti miliki. Peneliti (28 tahun) mulai mendapatkan malu terkait tubuh dari keluarga, teman, sampai orang yang hanya dikenal di media sosial, seperti:

Kamu gendut banget ih. 
Bulet banget tuh mukanya.

Kamu jangan gendut-gendut ih. Cowok gak ada yang mau.

Hal ini berbeda dengan A dan B yang mengalami malu terkait tubuh sejak kecil. Malu terkait tubuh yang dialami A sejak kecil dilakukan oleh keluarganya, khususnya oleh ibunya, dan tidak hanya berhubungan dengan berat badan, tapi juga tentang bentuk bagian badan tertentu. Malu terkait tubuh yang dialami A pun terus berlanjut ketika SMP, SMA, bahkan hingga berkuliah di jenjang doktoral.

Dari aku kecil keluarga aku sendiri juga suka body shaming. Jadi panggilan aku di rumah itu "Jenong”" (jidat lebar), "Monyong”, "Tangan Kuli", "Betis Kuli”, "Alis Shin-chan", "Muka Tua”.

B juga mengalami malu terkait tubuh sejak kecil yang dilakukan oleh berbagai pihak, baik keluarga, teman sekolah, pacar, dan teman di komunitas yang ia ikuti.

Gue pernah berantem sama cowok gue karena dia ngomentarin terus masalah berat badan. Jawabannya dia: "Habis kalau yang lain gak perlu dikomentarin, kalau misalnya tentang kemampuan, kompetensi, itu tuh gak pelu dikomentarin. Hal ini aja (berat badan) yang perlu dikomentarin, soalnya kan lu bisa ke arah yang lebih baik”.

Malu terkait tubuh yang diperoleh dari keluarga tidak disadari oleh B karena dianggap sebagai masukan yang membangun untuk menjadi lebih baik. Hal ini disebabkan karena malu terkait tubuh yang diterima B disampaikan dengan cara yang terselubung, yaitu badan yang gemuk bisa disiasati dengan memodifkasi pakaian agar terlihat kurus.

Waktu kecil keluarga gue sering banget bilang: "Kamu tuh cantik, gak papa badannya gemuk, tinggal pake baju hitam, nanti kita modifikasi biar keliatan kurus. Pokoknya yang penting gimana cara menyiasatinya, biar tetep cantik diliatnya." Itu sering banget disampein keluarga gue. 


\section{Alasan Melakukan Diet}

Peneliti, A, dan B, sama-sama memiliki keinginan untuk diet tetapi dengan alasan yang berbeda. Peneliti cukup terganggu dengan malu terkait tubuh, tetapi yang paling mengganggu adalah ketika peneliti mulai merasa tidak nyaman saat melakukan ibadah salat akibat obesitas tersebut. Lipatan lemak yang berada di kaki dan perut mengganggu peneliti ketika sujud dan rukuk sehingga menimbulkan rasa tidak nyaman. Setiap salat peneliti tidak merasakan kebahagiaan dan ketenangan seperti yang selama ini peneliti dapatkan sehingga membuat frustasi. Rasa frustasi itu membawa peneliti membulatkan tekad untuk menurunkan berat badan agar bisa salat lebih nyaman. Metode diet yang yang peneliti lakukan, yaitu mengurangi kadar minyak dan gula pada makanan yang dikonsumsi serta berolah raga rutin. Keputusan peneliti melakukan diet dengan metode ini menarik perhatian banyak orang di sekitar peneliti. Salah satu hal yang paling menarik perhatian orang lain adalah keputusan peneliti untuk tidak mengkonsumsi nasi untuk mengurangi asupan gula. Hal ini menjadi perhatian yang luar biasa bagi orang di sekitar karena nasi adalah makanan pokok orang Indonesia.

Adapun A dan B memiliki keinginan untuk diet karena malu terkait tubuh yang mereka alami. Malu terkait tubuh yang dialami A dari teman-temannya membuat A memiliki keinginan yang besar untuk menurunkan berat badan dan melakukan diet.

Terus dorongan yang bener-bener terjadi adalah waktu tahun 2018. Aku habis party ngerayain beres thesis defense sama temen-temen. Aku di-bully dikatain gendut lagi. Padahal kan aku lagi happy banget beres defense, eh malah dikata-katain. Akhirnya jam 5 pagi aku jogging. Mau pingsan rasanya karena aku jogging out of impulsive thinking and emotions.

Malu terkait tubuh yang dilakukan oleh kakak B dan temannya membuat B (27) memiliki keinginan untuk menurunkan berat badan.

Satu kakak gue pernah ngomong kayak gini, "Lu coba deh kurusin badan, pasti banyak cowok yang suka sama lu, pasti lu cakep banget." Kakak gue juga bilang, "Lu tuh cantik tau, cuma muka lu ketutupan pipi. Muka lu ketutupan leher." Dan di situ pun sebenernya salah satu yang mentrigger gue apakah gua harus berusaha untuk mencoba turunin berat badan.

\section{Dampak Negatif}

Pengalaman malu terkait tubuh memberikan berbagai dampak negatif bagi seluruh partisipan. Peneliti, A, dan B sama-sama merasakan berbagai emosi negatif. Frekuensi malu terkait tubuh yang 
terus muncul menghasilkan berbagai emosi negatif pada diri peneliti. Peneliti merasa marah karena orang lain hanya menilai seseorang dari fisiknya saja. Peneliti juga merasa sedih karena kritik tersebut datang dari sahabat dan keluarga yang diharapkan menjadi tempat paling aman dan nyaman justru tidak mendukung apa yang peneliti lakukan. Selama proses diet, banyak waktu yang peneliti habiskan sendiri. Peneliti berolah raga di saat orang lain tidak melakukannya. Peneliti juga tidak makan makanan yang biasa dimakan orang lain. Banyak momen yang membuat peneliti merasa sendirian.

A juga mengalami berbagai emosi negatif, seperti merasa kesal, sedih, benci, kecewa, baik kepada diri sendiri maupun orang lain.

Aku sangat kesel, sebel, benci, dan nahan-nahan nangis. Akhirnya begitu nyampe kamar, sendirian, aku nangis sesenggukan.

B juga merasakan berbagai emosi negatif seperti merasa jatuh, terpukul, sedih, kecewa, sampai menangis. B merasa sangat terpukul khususnya ketika dilakukan oleh keluarga.

Baru-baru ini gue sempet nangis banget. Waktu itu gue minta tolong nyokap gue buat nyebarin poster webinar. Terus tuh gue sedih banget. Instead of ngomongin webinarnya, tiba-tiba tuh nyokap bilangnya kayak gini: "B harusnya fotonya jangan yang itu, soalnya kalau yang itu keliatan gemuk." Ini gue jadi kepukul banget. Nyokap gua sendiri kayak gitu.

Di saat peneliti hanya merasakan emosi negatif, baik A dan B merasakan berbagai dampak negatif yang lebih banyak dibandingkan peneliti. A merasa bahwa kepribadiannya yang tidak percaya diri adalah hasil dari malu terkait tubuh yang ia alami sejak kecil. A selalu dibandingkan dengan kakaknya baik dari segi fisik maupun prestasi. Ibu A menjadikan penampilan fisik sebagai hal utama yang sering dikomentari.

Jadi akumulasi semua body shaming yang aku alami dari kecil membentuk kepribadian aku yang pemalu, gak PD, ngerasa super jelek, dan aneh. Aku malah mikir, apa yang aku lakuin gak akan pernah cukup gitu.

Pengalaman malu terkait tubuh juga memengaruhi tingkah laku A. A menjadi lebih sering memonitor beberapa bagian tertentu pada tubuhnya seperti kening dan lengan. 
Waktu mama bilang kayak gitu, aku lebih sadar gitu kalau lengan aku gede, makanya aku selalu pake cardigan atau pake baju lengan panjang. Aku jadi lebih aware sama bagian badan yang mamaku komen gitu. Terus misalnya mamaku bilang jenong, makanya aku selalu pake poni sampai sekarang.

A juga memiliki pemikiran negatif terhadap dirinya. Pemikiran ini memengaruhi bagaimana A memandang dirinya dan tubuhnya. A menjadi sangat takut dan berhati-hati dalam berpakaian.

Aku ngerasa diri aku "standar" karena aku pengen terlihat senormal mungkin. Padahal aku pengen pake baju yang lucu, tapi aku takut terlihat gemuk dan aneh. Aku takut baju yang aku pake malah menonjolkan semua body shaming yang orangorang lontarkan ke aku. Aku takut kalo pake jeans ini, paha dan betis aku terlihat besar. Aku takut kalo potong rambut begini, pipi aku terlihat makin tembem. Aku takut kalo aku iket rambut model begini, uban aku terlihat jelas dan orang-orang jadi jijik sama aku.

Malu terkait tubuh yang dialami A secara terus-menerus pun berdampak pada gejala gangguan makan yang A alami yaitu merasa bersalah ketika makan.

Aku juga jadi gak menikmati makanan yang aku makan. Aku setiap makan selalu ngerasa bersalah gitu. Apa yah... aku kayak takut jadi gendut lagi. Terus takut dibully lagi gitu loh, di body shaming lagi.

Adapun B mengalami gejala gangguan makan yang telah didiagnosis oleh psikolog yaitu binge eating dan bulimia. Ketika fase binge eating, B bisa memesan 3-4 kali makanan pesan antar dalam sekali makan dan mengkonsumsi mie instan 3-4 bungkus dalam satu kali makan. Ketika fase bulimia, B meminum empat butir obat laksatif setiap malam selama dua tahun.

I am currently handled by psychologist karena diagnosis sementara aku ada kecenderungan having mild eating disorder. Sebenernya through these past 8 years bentuknya beda-beda. Dari binge eating, bulimic, terus ke binge eating lagi.

\section{Strategi Pengelolaan Stres}

Ketika mendapatkan pengalaman malu terkait tubuh, baik peneliti, A, dan B memiliki strategi pengelolaan stres yang berbeda-beda. Ketika merasakan berbagai emosi negatif, peneliti mendapatkan energi dan dukungan dari lagu-lagu BTS. BTS adalah boyband asal Korea yang berhasil 
berkiprah di indutri musik internasional. Lagu-lagu BTS menemani peneliti bertahan dari malu terkait tubuh dan terus berusaha mencapai tujuan peneliti. Salah satu lagu BTS yang menemani peneliti berjudul Whalien 52. Lagu ini terinspirasi dari kisah nyata seekor paus yang bercerita tentang kesepian dan ketidakmampuan untuk dipahami dan berkomunikasi dengan paus lain karena nada frekuensinya yang lebih tinggi. Walaupun begitu, ia tetap percaya pada frekuensi suaranya. Ia tetap menyanyi dan berharap suatu saat suaranya berhasil didengar. Penggalan translasi lirik lagu Whalien 52 antara lain:

\section{Di tengah lautan luas}

Seekor paus berbicara dengan lembut dan kesepian

Fakta bahwa tidak peduli seberapa banyak mereka berteriak, itu tidak akan tercapai

Membuat mereka sangat kesepian sehingga mereka diam-diam menutup mulut

Saya menuju masa depan saya

Pantai biru itu dan

Percaya pada hertz saya

Ketika mendengar lagu ini, peneliti merasa tidak sendirian. Peneliti merasa apa yang peneliti alami mirip dengan apa yang paus alami, seperti yang dialami BTS di awal masa kariernya. Peneliti merasa si paus dan BTS menjadi teman dan memberi kekuatan untuk tetap diet dan melakukan pola hidup sehat demi mencapai tujuan peneliti.

Hal ini berbeda dengan strategi yang dilakukan oleh A dan B. Ketika mendapatkan malu terkait tubuh, A cenderung diam. Hal ini disebabkan karena A merasa tidak mampu membela diri.

Aku berusaha senyum, tapi aku paling gak bisa ngebela diri. Aku gak pernah bilang kalau aku gak nyaman diperlakukan kayak gitu, karena simply aku gak bisa.

Aku cuman iya-iya aja. Pernah aku agak ngelawan, mereka ngatain aku baper.

Adapun B mencoba untuk melihat hal yang positif dari suatu masalah. B mendapat inspirasi dari buku yang berjudul "Glass Half Empty, Glass Half Full”.

Sebenernya gue gak baca bukunya langsung. Gue diceritain temen gue waktu SMA tentang buku judulnya Glass Half Empty, Glass Half Full. Buku itu bilang lu fokus sama air yang ada, bukan gelas yang kosong. Itu waktu SMA dan cukup berbekas di gue sampe sekarang. 
Ketika mengalami malu terkait tubuh, B berusaha untuk memahami alasan orang yang melakukannya. B juga berusaha mempertanyakan apakah yang dilakukan orang lain mempermalukannya atau bukan. Upaya berpikir positif ini cenderung membuat B melakukan rasionalisasi terhadap malu terkait tubuh yang ia alami.

Terus gue mencoba mengingat apa yang sudah dilakukan nyokap gue. Terus gue mikir oh mungkin maksudnya nyokap gue tuh berusaha untuk ngasih tau yang baik. Karena mungkin menurut dia, di foto itu tuh gue terlihat gemuk. Jadi dia tuh ngasih saran. Gue sih mencoba positif thinking saat itu.

B mengaku memiliki nilai utama harmoni dalam hidupnya. Nilai ini juga yang membuat B cenderung menghindari rasa sakit dan menghindari konflik ketika mengalami malu terkait tubuh.

Hal yang penting dari hidup gue adalah harmonisasi. Menurut gue semua hal itu perlu harmoni, come with peace. Harmoni itu jadi value gue. Body shaming jadi suatu hal yang negatif buat gue. Berusaha memahami kenapa orang melakukan body shaming dan mempertanyakan apakah itu body shaming atau bukan adalah cara gue untuk melakukan harmonisasi di diri gue.

\section{Malu Terkait Tubuh Saat dan Setelah Diet}

Malu terkait tubuh dialami oleh peneliti, A, dan B secara terus-menerus, baik sebelum diet, saat diet, bahkan setelah diet. Komentar negatif terhadap keputusan diet peneliti dapatkan selama diet berlangsung, baik dari keluarga maupun rekan kerja: "gak usah berlebihan lah, dietnya", "freak banget sih dietnya", "paling gak bertahan lama diet-diet kayak gini, hahaha". Bahkan, malu terkait tubuh pun tetap peneliti alami bahkan ketika peneliti sudah selesai diet.

Balik lagi kayak dulu dong badannya, yang sekarang tuh kayak bukan kamu, jelek kalau terlalu kurus.

Sekarang mah kurus ya, dulu besar banget, hahahaha.

Dulu pas bulet banget ngeliat jalannya aja engap [susah bernafas], lambat, sesak nafas liatnya, hahahaha.

Kalimat-kalimat di atas menunjukkan bentuk dari malu terkait tubuh karena ketika peneliti memiliki tubuh yang kurus, peneliti tetap mendapat kritik memiliki tubuh yang jelek. Orang tersebut 
juga menertawakan masa-masa ketika peneliti berbadan gemuk dan menjelek-jelekan bahwa peneliti berjalan lambat dan membuat sesak nafas.

Hal ini juga terjadi pada A dan B. Ketika A berusaha melakukan diet, A tetap mendapatkan komentar negatif dari teman-temannya. Begitu pula dengan B, yang setelah diet dan berat badannya sudah mengalami penurunan, malu terkait tubuh tetap dilakukan oleh teman-teman di komunitasnya.

Mereka bilang "Diet dan olah raga macem apa yg kamu lakuin? Sia-sia kayaknya, kamu sama aja, gak ada bedanya, tetep gendut".

Waktu gue menang perlombaan di komunitas, pernah ada yang komentar, "Wah yang menang si B. Gimana tuh nanti, orang badannya kayak mbok-mbok”. Waktu ngedenger itu tuh gue down parah.

\section{Dampak Positif}

Berbeda dengan A dan B, peneliti mendapatkan dampak positif dari pengalaman malu terkait tubuh. Walaupun merasakan berbagai emosi negatif, dengan terus berolah raga dan makan makanan sehat, dalam empat bulan secara bertahap berat badan peneliti yang semula $83 \mathrm{~kg}$ turun mencapai 60 kg. Akhirnya, peneliti dapat salat dengan nyaman. Selain itu, peneliti menjadi memiliki gaya hidup yang lebih sehat, jarang sakit, wajah lebih cerah, merasa lebih kuat secara fisik dan mental, tidak mudah stres, serta mendapatkan teman-teman baru sesama penggemar BTS dan dari kegiatan olah raga. Peneliti juga memiliki pencapaian baru dalam olah raga. Peneliti yang awalnya melakukan olah raga lari hanya untuk diet dan memulainya sejauh $2 \mathrm{~km}$, saat ini sanggup lari sampai $32 \mathrm{~km}$ dan berhasil menyelesaikan perlombaan lari half marathon di salah satu perlombaan maraton di Indonesia. Atas dukungan dari orang di sekitar dan setelah mempertimbangkan banyak hal, peneliti memberanikan diri untuk menulis perjalanan diet peneliti di media sosial. Tujuannya agar manfaat yang peneliti rasakan dapat dirasakan juga oleh orang lain. Emosi negatif yang muncul dari malu terkait tubuh, seperti marah, sedih, kecewa, dan merasa sendirian digunakan sebagai dorongan untuk menulis dan berkarya. Peneliti menuliskan pengalaman malu terkait tubuh yang peneliti alami dan diet yang dilakukan di Instagram Story (Instastory) sebanyak 15 seri tulisan. 


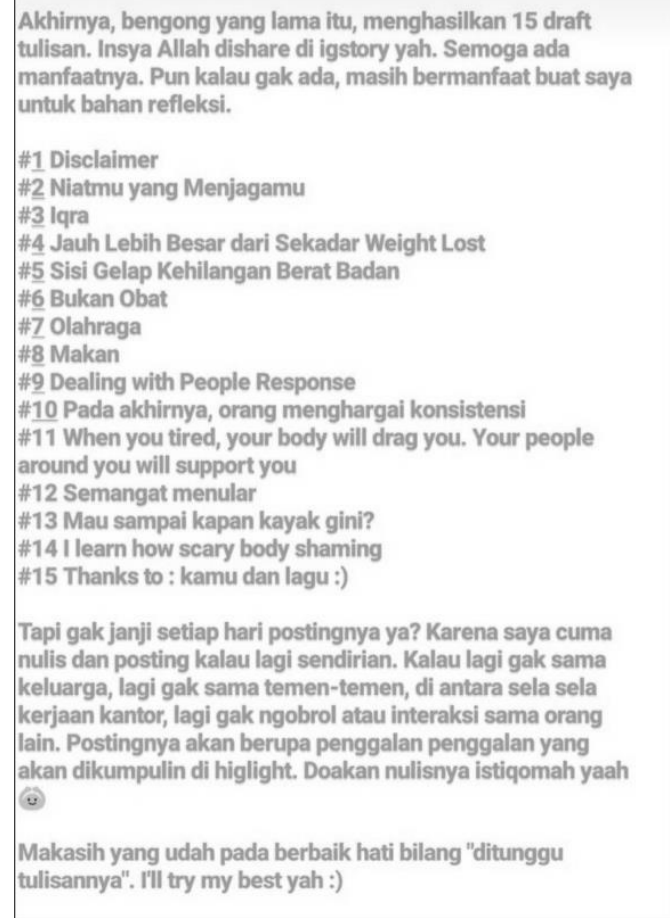

Figur 1. Cuplikan Tulisan di Instastory Peneliti

(sumber: Akun Instagram Peneliti)

Tulisan ini dipublikasikan secara bertahap selama 3 bulan. Tulisan-tulisan tersebut mendapatkan sambutan positif dari banyak orang. Hal yang tidak peneliti bayangkan sebelumnya adalah melalui tulisan tersebut, beberapa orang membuka diri mengenai pengalaman malu terkait tubuh dan gangguan makan yang mereka alami, termasuk A dan B. Peneliti menjadi tahu bahwa malu terkait tubuh dapat berdampak pada kesehatan mental dan mengganggu keberhargaan diri seseorang. Sebagai Sarjana Psikologi dan memiliki cita-cita sebagai psikolog, peneliti merasa malu mendapati diri peneliti yang seolah tidak peduli dengan fenomena ini sebelumnya. Peneliti mengalami malu terkait tubuh, tetapi tidak merasakan dampak negatif yang berarti selain emosi negatif. Rasa malu tersebut mendorong peneliti untuk berusaha memahami fenomena ini lebih lanjut sehingga peneliti mewawancarai dua orang yang menceritakan pengalaman malu terkait tubuh yang dialami, yaitu A dan B.

\section{Dukungan Menghadapi Malu terkait Tubuh}

Seluruh pasrtisipan sama-sama mendapatkan dukungan dari karya orang lain ketika mengalami malu terkait tubuh. Peneliti mendapatkan dukungan dari lagu-lagu BTS, sedangkan A dan 
B mendapatkan dukungan sejak membaca tulisan peneliti di Instastory. Sejak saat itu, A (29) berusaha untuk memiliki pola makan dan aktivitas fisik yang lebih baik.

Aku lebih bahagia sejak sering makan sehat dan lebih banyak gerak. Aku sejak baca instastory kamu, aku ngerasa ada seseorang yang jadi penguat aku. Walaupun kita gak kenal deket dan jauh, tapi tulisan kamu bener-bener menolong. Makasih. Dari baca-baca sharing kamu, entah kenapa hati aku ngerasa hangat dan manggutmanggut senyum sendiri. Makasih.

Setelah berdiskusi dengan peneliti, A juga mulai mencoba menyampaikan rasa tidak sukanya atas malu terkait tubuh yang ia alami. A berusaha menyampaikan rasa tidak nyamannya kepada orang-orang yang melakukannya.

Akhirnya aku confront mereka yang ngejek aku. Aku bilang, "Gue gak mau lagi makan sama lu. Kalau makan bareng atau ngumpul bareng, lu pasti komenin gendut terus. Gua capek”. Sekarang tuh kayaknya mereka tau kalau aku serius. Jadi mereka lebih tau diri.

B mendapatkan dukungan menghadapi malu terkait tubuh melalui buku yang ia baca. Selain itu, setelah membaca tulisan peneliti di Instastory, B mulai berpikir untuk membuka diri dan menceritakan pengalaman malu terkait tubuh dan gangguan makan yang ia alami. B (27) berharap agar apa yang ia alami tidak dialami oleh orang lain.

\section{DISKUSI}

Penelitian ini bertujuan untuk mengeksplorasi bagaimana pengalaman dan pemaknaan individu terhadap malu terkait tubuh. Penelitian terdahulu mengindikasikan berbagai dampak negatif dari malu terkait tubuh (Chairani, 2018; Tylka dkk., 2014; Veerman, 2013). Malu terkait tubuh yang dialami oleh peneliti dan kedua partisipan sama-sama memunculkan emosi negatif, seperti sedih, kesal, marah, dan kecewa. Peneliti dan kedua partisipan pun sama-sama memiliki keinginan untuk melakukan diet dan menurunkan berat badan, walaupun dengan alasan yang berbeda. Selain itu, malu terkait tubuh yang dialami peneliti dan kedua partisipan juga terjadi secara berlarut-larut, yaitu ketika gemuk, ketika melakukan diet, dan ketika sudah kurus. Hal ini sesuai dengan penelitian sebelumnya yang menyatakan bahwa di Indonesia, memberikan komentar terkait tubuh menjadi hal yang 
dianggap normal, sehingga fenomena ini tetap bertahan (Soleman \& Elindawati, 2019), baik ketika seseorang gemuk maupun kurus.

Kritik terkait tubuh biasa dilakukan untuk mengungkapkan ketidaksetujuan dan ketidaknyamanan terkait bagian tubuh orang lain karena tidak sesuai dengan konstruk tubuh ideal yang ada di pikiran seseorang. Kebiasaan ini membentuk kerangka berpikir bahwa memberikan kritik terkait tubuh adalah sesuatu yang normal untuk dilakukan. Pada penelitian ini ditemukan bahwa dampak dari malu terkait tubuh tidak semuanya negatif. Malu terkait tubuh dapat menjadi salah satu sumber stres. Strategi pengelolaan masalah yang dilakukan partisipan juga berbeda, dipengaruhi latar belakang dan nilai yang dimiliki. Peneliti cenderung melakukan startegi koping yang berfokus pada masalah dengan cara olah raga dan melakukan pola makan yang sehat, sedangkan kedua partisipan lainnya cenderung melakukan strategi koping yang berfokus pada emosi, yaitu dengan cara diam, menghindar, atau rasionalisasi. Strategi pengelolaan stres yang tidak tepat, seperti menghindar dan melakukan rasionalisasi akan membawa individu pada perilaku yang tidak tepat (maladaptif) (Farid \& Kamrani, 2016). Perbedaan strategi pengelolaan stres yang berbeda ini yang memungkinkan peneliti mendapatkan dampak positif yang tidak dirasakan oleh A dan B.

Selain itu, perbedaan ini tampaknya berkaitan dengan latar belakang partisipan yang berbeda. Peneliti selalu dihargai berdasarkan prestasi dan bukan berdasarkan bentuk tubuh. Peneliti pun tidak pernah mengalami malu terkait tubuh sampai usia dewasa muda ketika peneliti mengalami stres yang menyebabkan obesitas. Pada usia dewasa muda, ciri kepribadian relatif lebih stabil (Papalia \& Feldman, 2012), sehingga pengalaman malu terkait tubuh yang peneliti rasakan hanya memiliki sedikit dampak yang merugikan. Sementara itu, kedua partisipan lainnya mengalami malu terkait tubuh sejak kecil sampai dewasa dari keluarga dan teman, dan menyangkut bukan hanya berat badan, tetapi juga bentuk bagian tubuh lainnya. Pada usia anak-anak, konsep diri masih mengalami perkembangan dan dapat mempengaruhi self-esteem (Papalia \& Feldman, 2012). Selain itu, pengasuhan orang tua dan evaluasi negatif dari teman sebaya memiliki hubungan dengan masalah citra tubuh dan keberhargaan diri secara fisik (Michael dkk., 2014). Pengalaman malu terkait tubuh yang dialami sejak kanak-kanak tampaknya memengaruhi pembentukan konsep diri kedua partisipan, sehingga mengalami dampak negatif yang lebih banyak, seperti memengaruhi konsep diri, memiliki citra tubuh negatif, dan takut salah dalam berpakaian.

Seluruh partisipan mengalami gejala gangguan makan seperti makan berlebihan, binge eating, bulimia, dan rasa bersalah ketika makan, sejalan dengan penelitian yang menemukan bahwa malu terkait tubuh dapat menjadi prediktor yang sangat kuat terhadap gangguan makan (Chairani, 2018). 
Akan tetapi, gangguan makan yang dialami peneliti di saat bekerja tidak berkepanjangan hingga bersifat klinis karena peneliti menggunakan strategi yang efektif, yaitu melakukan hal-hal yang diperlukan untuk mengatasi masalah secara realistis dan rasional (Farid \& Kamrani, 2016), dengan cara mengubah pola makan dan berolah raga untuk mengurangi berat badan dan lebih sehat. Pengalaman malu terkait tubuh yang peneliti alami memberikan beberapa dampak positif, seperti berat badan ideal, merasa lebih nyaman untuk salat, dan mencapai prestasi dalam olah raga marathon, serta keberanian untuk berbagi pengalaman berupa tulisan di Instastory. Hal ini berbeda dengan yang dialami A yang masih merasa bersalah ketika makan dan B yang mengalami gangguan makan yang bersifat klinis.

Tulisan yang ditulis peneliti di Instastory memberi informasi kepada orang lain terkait malu terkait tubuh, pola makan, dan olah raga. Ternyata, tulisan tersebut berhasil membuat kedua partisipan mau berbagi cerita, sehingga lebih memahami malu terkait tubuh yang mereka alami, serta mengubah strategi mereka yang tidak tepat (koping berfokus pada emosi) menjadi lebih terarah ke penyelesaian masalah. Tampak bahwa ketika mengalami malu terkait tubuh, individu membutuhkan dukungan. Dalam hal ini, peneliti dan kedua partisipan mendapat pemahaman yang mendalam dan dukungan dari karya orang lain. Peneliti mendapatkan dukungan dan energi dari lirik lagu, sedangkan kedua partisipan mendapatkan dukungan dari tulisan di Insastory peneliti dan buku karya orang lain.

Terdapat beberapa keterbatasan yang dimiliki oleh penelitian ini, yaitu malu terkait tubuh yang dialami oleh partisipan pada penelitian ini lebih banyak dilakukan melalui komunikasi verbal secara langsung. Peneliti belum mengeksplorasi lebih mendalam mengenai pengalaman malu terkait tubuh yang dialami secara online atau melalui media sosial. Keterbatasan lainnya adalah malu terkait tubuh yang diteliti pada penelitian ini hanya pada perempuan dan dalam konteks obesitas/overweight, sementara malu terkait tubuh dapat terjadi dalam berbagai bentuk, seperti terlalu kurus, bentuk tubuh yang tidak biasa, dan lain-lain. Selain itu, proses refleksi mandiri yang dilakukan oleh partisipan A dan B tidak didokumentasikan dalam bentuk tertulis melainkan hanya melalui rekaman proses wawancara.

\section{SIMPULAN DAN SARAN}

\section{Simpulan}

Hasil penelitian ini menunjukkan bahwa pemaknaan terhadap malu terkait tubuh dan strategi dalam menghadapinya tidak terlepas dari riwayat kehidupan individu, khususnya yang berhubungan 
dengan pengalaman awal tentang hal-hal yang dianggap berharga pada diri seseorang, seperti prestasi atau bentuk tubuh. Pengalaman malu terkait tubuh dapat menimbulkan berbagai emosi negatif. Strategi pengelolaan yang tepat dapat mengurangi dampak negatif, bahkan menghasilkan dampak positif, yaitu membangun pola hidup yang lebih sehat. Sementara itu, strategi pengelolaan masalah yang tidak tepat cenderung menyebabkan dampak negatif yang berkepanjangan dan masalah gangguan makan. Ketika individu mendapatkan dukungan dari lingkungan, mereka dapat mengubah strateginya menjadi lebih tepat serta mengatasi dampak negatif dari malu terkait tubuh.

\section{Saran Teoretis}

Hasil penelitian ini menunjukkan bahwa pengalaman malu terkait tubuh bukanlah pengalaman yang terjadi satu kali, melainkan secara terus-menerus di berbagai fase kehidupan individu, baik ketika gemuk maupun kurus, bahkan menyangkut bentuk bagian tubuh tertentu. Dibutuhkan penelitian lebih lanjut mengenai dinamika pengalaman malu terkait tubuh dan dampaknya di berbagai fase kehidupan individu yang memungkinkan adanya perbedaan pemaknaan dan reaksi terhadap malu terkait tubuh. Pada penelitian ini, nilai-nilai yang dimiliki individu juga memengaruhi strategi koping yang dilakukan dalam menghadapi malu terkait tubuh. Pada studi selanjutnya juga dapat dilihat hubungan antara kepribadian dengan pemaknaan, reaksi, serta bentuk koping individu terhadap malu terkait tubuh.

\section{Saran Praktis}

Hasil penelitian ini menunjukan bahwa malu terkait tubuh dapat memberikan berbagai dampak yang negatif pada individu, namun juga dapat berdampak positif apabila dikelola dengan baik. Hasil penelitian ini dapat membantu praktisi klinis untuk menyusun metode intervensi dan rancangan konseling yang tepat bagi individu yang mengalami malu terkait tubuh. Yang khas Indonesia yang ditemukan dalam penelitian ini adalah pentingnya dukungan sosial, mulai dari orang terdekat hingga figur atau karya yang menginspirasi, sehingga pedoman ini dapat digunakan oleh praktisi klinis dalam mengidentifikasi sumber dukungan dan membantu individu mengembangkan strategi koping yang efektif dalam menghadapi malu terkait tubuh. 


\section{REFERENSI}

Adams, T. E., Jones, S. H., \& Ellis, C. (2015). Autoetnography understanding qualitative reasearch. Oxford University Press.

Albertson, E. R., Neff, K. D., \& Dill-Shackleford, K. E. (2015). Self-compassion and body dissatisfaction in women: A randomized controlled trial of a brief meditation intervention. Mindfulness, 6(3), 444-454. https://doi.org/10.1007/s12671-014-0277-3

Alysse Bailey, K., Lamarche, L., Gammage, K. L., \& Sullivan, P. J. (2016). Self-objectification and the use of body image coping strategies: The role of shame in highly physically active women. American Journal of Psychology, 129(1), 81-90. https://doi.org/10.5406/amerjpsyc.129.1.0081

American Psychiatric Association. (2013). Diagnostic and statistical manual of mental disorders $\left(5^{\text {th }}\right.$ ed.). Author.

Bordo, S. (1993). Unbearable weight: Feminism, western culture, and the body. University of California Press.

Chairani, L.-. (2018). Body shame dan gangguan makan kajian meta-analisis. Buletin Psikologi, 26(1), 12-27. https://doi.org/10.22146/buletinpsikologi.27084

Damanik, T. M. (2018). Dinamika psikologis perempuan mengalami body shame [Skripsi tidak dipublikasikan, Universitas Sanata Dharma Yogyakarta]. https://repository.usd.ac.id/30840/2/119114172_full.pdf

Farid, M., \& Kamrani, M. A. (2016). The relationship between body image coping strategy and Eeting disorders among Iranian adolescent girls. Bali Medical Journal, 5(1), 15-19. https://doi.org/10.15562/bmj.v5i1.151

Fauzia, T. F., \& Rahmiaji, L. R. (2019). Memahami pengalaman body shaming pada remaja perempuan. Interaksi Online, 7(3), 238-248.

Fredrickson, B. L., \& Roberts, T. A. (1997). Toward understanding women's lived experiences and mental health risks. Psychology of Women Quarterly, 21(2), 173-206. https://doi.org/10.1111/j.1471-6402.1997.tb00108.x

Jones, S. H., Adams, T. E., \& Ellis, C. (2016). Handbook of autoethnography. Routledge.

Katz, B. (2014). Gender and disordered eating of adolescents in Israel. The Israel Journal of Psychiatry and Related Sciences, 2(5), 137-144.

Lazarus, R. S., \& Folkman, S. (1984). Stress, appraisal, and coping. Springer Publishing Company.

Michael, S. L., Wentzel, K., Elliott, M. N., Dittus, P. J., Kanouse, D. E., Wallander, J. L., Pasch, K. 
E., Franzini, L., Taylor, W. C., Qureshi, T., Franklin, F. A., \& Schuster, M. A. (2014). Parental and peer factors associated with body image discrepancy among fifth-grade boys and girls. Journal of Youth and Adolescence, 43(1), 15-29. https://doi.org/10.1007/s10964-012-9899-8

Moustakas, C. (1994). Phenomenological research methods. Sage Publications. https://doi.org/10.4135/9781412995658

Newman, T. (2017, Juli 17). Nine most popular diets rated by experts 2017. Medical News Today. https://www.medicalnewstoday.com/articles/5847

Nishida, C., Barba, C., Cavalli-Sforza, T., Cutter, J., Deurenberg, P., Darnton-Hill, I., DeurenbergYap, M., Gill, T., James, P., Ko, G., Kosulwat, V., Kumanyika, S., Kurpad, A., Mascie-Taylor, N., Moon, H. K., Nakadomo, F., Nishida, C., Noor, M. I., Reddy, K. S., ... Zimmet, P. (2004). Appropriate body-mass index for Asian populations and its implications for policy and intervention strategies. The Lancet, 363(9403), 157-163. https://doi.org/10.1016/S01406736(03)15268-3

Papalia, D. E., \& Feldman, R. D. (2012). Experience human development (12th ed.). McGraw-Hill.

Pricilia, C., Yoanita, D., \& Budiana, D. (2019). Pengaruh bodily shame di Instagram terhadap konsep diri remaja perempuan. Jurnal E-Komunikasi, 7(2), 1-12. http://publication.petra.ac.id/index.php/ilmu-komunikasi/article/view/10282

Quittkat, H. L., Hartmann, A. S., Düsing, R., Buhlmann, U., \& Vocks, S. (2019). Body dissatisfaction, importance of appearance, and body appreciation in men and women over the lifespan. Frontiers in Psychiatry, 10(Article 864), 1-12. https://doi.org/10.3389/fpsyt.2019.00864

Rosita, T., Irmayanti, R., \& Hendriana, H. (2019). Body shame pada Siswa. Journal of Innovative Counseling: Theory, Practice \& Research, 3(2), 76-82. https://www.journal.umtas.ac.id/index.php/innovative_counseling/article/view/569\%0AVol

Soleman, N., \& Elindawati, R. (2019). Fourth wave feminism in Indonesia: Body shaming through social media phenomenon. Journal of Islamic World and Politics, 3(2), 588-604. https://doi.org/10.18196/jiwp.3234

Tylka, T. L., Annunziato, R. A., Burgard, D., Daníelsdóttir, S., Shuman, E., Davis, C., \& Calogero, R. M. (2014). The weight-inclusive versus weight-normative approach to health: Evaluating the evidence for prioritizing well-being over weight loss. Journal of Obesity, 2014(4), 1-18. https://doi.org/10.1155/2014/983495

Undang-Undang Republik Indonesia Nomor 11 Tahun 2008 Tentang Informasi dan Transaksi Elektronik, Pub. L. No. Nomor 11 Tahun 2008, 1 (2008). papers3://publication/uuid/8C845E4E- 


\section{CD67-4476-BB4F-7123C56F0449}

Vargas, E. (2021). Body shaming: What is it \& why do we do it? Walden Behavior Care. https://www.waldeneatingdisorders.com/blog/body-shaming-what-is-it-why-do-we-do-it/

Veerman, E. (2013). Supporting women with a negative body image. Practice Nursing, 24(3), 137140. https://doi.org/10.12968/pnur.2013.24.3.137

Webb, J. B., Fiery, M. F., \& Jafari, N. (2016). "You better not leave me shaming!": Conditional indirect effect analyses of anti-fat attitudes, body shame, and fat talk as a function of selfcompassion in college women. Body Image, 18, 5-13. https://doi.org/10.1016/j.bodyim.2016.04.009

Yoder, J. D. (2013). Women and gender: Making a difference (4th ed.). Sloan Publishing. 